Relations industrielles

Industrial Relations

\title{
Pension Power: Unions, Pension Funds and Social Investment in Canada, by Isla CARMICHAEL, Toronto: University of Toronto Press, 2005, 225 pp., ISBN 0-8020-3647-3.
}

\section{Frédéric Hanin}

Volume 61, numéro 3, été 2006

URI : https://id.erudit.org/iderudit/014192ar

DOI : https://doi.org/10.7202/014192ar

Aller au sommaire du numéro

\section{Éditeur(s)}

Département des relations industrielles de l'Université Laval

\section{ISSN}

0034-379X (imprimé)

1703-8138 (numérique)

Découvrir la revue

Citer ce compte rendu

Hanin, F. (2006). Compte rendu de [Pension Power: Unions, Pension Funds and Social Investment in Canada, by Isla CARMICHAEL, Toronto: University of Toronto Press, 2005, 225 pp., ISBN 0-8020-3647-3.] Relations industrielles / Industrial Relations, 61(3), 545-547. https://doi.org/10.7202/014192ar

Tous droits réservés @ Département des relations industrielles de l'Université Laval, 2006
Ce document est protégé par la loi sur le droit d'auteur. L'utilisation des services d’Érudit (y compris la reproduction) est assujettie à sa politique d'utilisation que vous pouvez consulter en ligne.

https://apropos.erudit.org/fr/usagers/politique-dutilisation/ 
The authors conclude by pointing out factors that underpin the East Asian welfare regimes. These include, besides the already mentioned role of Confucianism, the fact that these are rapidly developing societies, influencing the pace of welfare reforms and the challenges - such as migration - to which welfare has to respond, and yet this aspect is hardly discussed in the literature on welfare in the region. Second, neo-liberalism has been the dominant force in social policy development, imposing the primacy of economic development over social welfare; this coincides with the residual character of welfare that corresponds to the Confucian approach. Thirdly, in all countries, authoritarian state power has been used to force the pace of industrialization and to use ideology to legitimate its repressive policies. The financial crisis, an obvious feature of recent globalization, has transformed social policy because economic growth has declined, stifling the funding source for public welfare spending, while unemployment has increased, impacting on individual and family incomes, the other source of welfare. In Hong Kong, globalization reinforced the market orientation and anti-welfarism of the ruling elites. In Japan, it reduced job security, but in the face of declining family responsibility, the government increased private welfare provision.

To sum up, this volume fills a gap in comparative social policy research. It is an informative and well-documented book about past and present developments in East Asian countries usually not found together in one volume. It is a useful reference for policy makers, social partners (employers' organizations and trade unions) and other civil society actors.

Hedva Sarfati

ISSA Consultant on labour market and welfare reforms, Geneva, Switzerland

\section{Pension Power: Unions, Pension Funds and Social Investment in Canada, \\ by Isla CARMichael, Toronto: University of Toronto Press, 2005, 225 pp., ISBN 0-8020-3647-3.}

This volume provides an analysis of the power of unions to implement "radical change in the role that the labour movement in Canada plays in the economy" through the control of pension funds and social investment policy. Social investment is defined as: "collaborative action taken by unions and pension funds, leading to various types of collateral investment, which implicitly or explicitly challenge conventional corporate behaviour, and through use of social accounting techniques, provide a verifiable contribution to the social and economic benefit of the community" (p. 160). Pension power, therefore, is a part of the renewal of unions in Canada after the demise of the fordist collective agreement. This theme is discussed in many other western countries as well, and is generally referred to by the term "Working Capital." The objective is both to change existing investment practices on the part of financial managers and to develop financial innovations for the benefit of workers.

Pension management issues are highly important for industrial relations. Pension "activists" are proponents of economic democracy and of the social responsibility of capital owners. However, the present trend in pension reforms and the macroeconomic context are not favourable to the socialization of investment (an idea already promoted by the "New Liberals," such as John Maynard Keynes at the beginning of the twentieth century). New public management, lean management, and 
shareholder-oriented corporate governance have contributed to the increasing popularity of individual retirement systems for workers.

The first part of the book presents the state of the debate about pension fund management in Canada. Pension funds have been created through successive legislation and government intervention to develop, regulate and sustain Canada's retirement income system. In the seventies, pension fund investment was an important source of capital for the government. Since that time, successive acts of legislation have promoted private securities holding through tax credits.

As most pension funds are registered under trust law, the "prudent man" rule is central to gauging the motives of trustees. The author argues that this rule is central to the understanding of the financial sector control of pension funds. The meaning of the rule has nonetheless evolved under successive interpretations and is now in accordance with modern portfolio theory, synonymous with asset return maximization and portfolio diversification. Since the seventies, the behaviour of trustees has then been governed by efficient market theory which prevents social investment. In this perspective, money managers cannot beat the market and should favour passive management which consists of creating portfolios similar to the market. Financial risk and return are therefore the only information needed to run pension funds.

For union activists, passive financial management should be converted into social investment and shareholder activism. Social investment usually refers to the inclusion of various social standards in investment decision-making, and shareholder activism describes a whole range of actions to force corporate accountability. Both strategies aim at introducing social and ethical indicators to evaluate corporate performance through the evolution of accounting standards and the development of venture capital and economically targeted investment. Venture capital is a fund which invests only in private companies. In its social form, venture capital helps small and medium firms to develop local markets which hold no investment interest for the financial sector. Economically targeted investment (ETI) is a form of investment which produces collateral benefits in a targeted geographic area, group of people or sector of the economy. For example, ETI was used by Ontario Municipal Employees Retirement System to invest in publicprivate partnerships.

Isla Carmichael's book, which supports social pension fund management, deals with a highly debated issue, because not all unions are hostile to financial management of pension funds. It is generally considered that, thanks to independent financial management, events such as those of Enron or Maxwell may be less likely to occur and employers will not be able to use workers' deferred income as a source of cheap capital for the company. In the public sector, financial management is advocated by unions so as to prevent governments from implementing shortterm human resource management policy or from financing current deficits with pension money.

Nonetheless, unions are both organizations and a social movement. Passive pension fund management may improve the former but at the expense of the latter when unions are associated with financial sector rhetoric.

The second and the third parts of the book document local experience and future research into social investing in Canada. Through the case study of Concert Properties, a company which provides affordable housing in the Vancouver region, Isla Carmichael analyses the best ways to implement social investing in Canada. 
She builds up a social accounting statement of Concert's investments to find out the value added created for union members and local communities by Concert's investments. Social accounting is important in the evaluation of collateral benefits. Concert Properties' study is a good example of how difficult it is for unions to connect private and social levels of action because Concert must be financially viable in order to promote social investment. The intricate thing is then to combine business with collective objectives through governance rules. In this perspective, the author calls for future research into the governance of social investment organizations such as the Caisse de Dépôt et Placement du Québec or labour-sponsored investment funds.

Social accounting also sheds light on the role of public policy for the success of social investment. The Concert initiative would not have been possible without the municipal government of Vancouver which found the land for development and leased it on a longterm basis. Without taking into account induced and indirect effects of the activity created by Concert, all governments have experienced a net loss in terms of tax revenues. But, the loss becomes a gain when Isla Carmichael uses multipliers to evaluate induced and indirect effects of Concert's spending. It is, therefore, highly important to undertake a broad accounting perspective to measure the benefits of social investment. It is important to notice that accounting for social investment rests on important assumptions about employment and value added multipliers because these are derived from input-output analysis within which public policy parameters are central (the unemployment rate, labour costs and many aspects of the employment relation).

Social accounting, as described in the book, is a first step towards a set of accounting principles for stakeholders. It is important to notice that labour intensive production, low heterogeneity of working conditions and a stable labour legislative framework are important assumptions for social accounting.

The idea of Pension Power is symptomatic of the demise of the fordist governance, which has led unions to interfere with capital management, a sphere originally devoted to employers and financiers. That's why there still exists a debate among unions about social investment, opponents considering that social investment may justify the private regulation of pension funds and financial sector leadership.

Pension Power is a book which concerns practitioners and scholars of industrial relations as well, in the new era of corporate social responsibility and sustainable development. The debate about Pension Power raises a larger one about the sufficient conditions to restore the balance between capital and labour in order to improve social conditions for workers.

Frédéric HaNin Université Laval

United Apart: Gender and the Rise of Craft Unionism, by Ileen A. DeVAult, Ithaca, N.Y.: Cornell University Press, 2004, 244 pp., ISBN 0-8014-8926-1 (paper).

United Apart: Gender and the Rise of Craft Unionism by Ileen A. DeVault is an investigation into the place of women in the American trade union movement in the years following its formation.
Although she discusses the Knights of Labour, her particular interest is the AFL. Her inquiry "involves the ways in which the unions that made up the AFL came to encode gender into their 